\title{
Organisasi dan Pengembangan SDM
}

\author{
Oleh Supardi
}

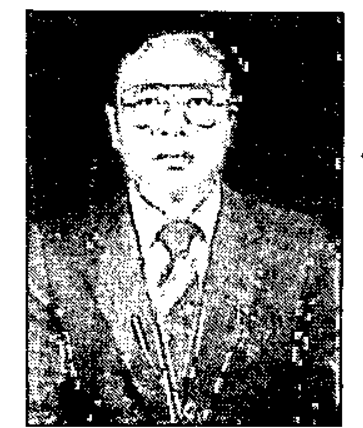

Drs. Supardl, MM, lahir di Klaten bulan April 1952. Seorang Alumni Fakultas Ekonomi UII Tahun 1978. Dosen dpk. di UIl mulai 1980, sampai sekarang sebagai Lektor (IVa) pada Fakultas Ekonomi UII. Pernah sebagai Sekretaris Redaksi Majalah Triwulanan "UNISIA" UII ( 1982 - 1986). Karya yang dipublikasikan dalam bentuk buku 8 judul buku dan yang terakhir buku metodologi penelitian bisnis (1993). Menulis di majalah UNISIA, ALMAMATER, KAJIAN BISNIS dan hasil-hasil penelitian baik penelitian individual maupun kelompok sejak menjadi dosen FE UII.

Mata kuliah yang dibina sampai sekarang adalah Manajemen Personalia (SDM); Manajemen; Pembelanjaan Perusahaan, Studi Kelayakan Proyek dan Metodologi Penelitian

Pendahuluan

"Organisasi" merupakan sarana atau alat yang lazim dipergunakan oleh setiap bentuk kerjasama dari kelompok individu-individu. yang sistematis dalam rangka mendapai tujuan bersama yang telah disepakatinya.

Setiap organisasi yang telah disepakati dalam suatu kelompok individu-individu akan terjadi interaksi hubungan antar individu. Dengan adanya kebutuhan interaksi secara teratur dan sistematis maka dalam organisasi akan timbul kesepakatan untuk menentukan kepemimpinan kelompok (organisasi) tersebut.

Dengan demikian pembicaraan tentang pembinaan organisasi tidak akan terlepas dari pembahasan tentang SDM organisasi, dalam rangka pencapaian tujuan organisasi yang telah disepakati secara efektif dan efisien.

Suatu organisasi dapat dianggap baik, jikalau organisasi tersebut dapat berfungsi secara optimal sebagai "wadah". dan alat yang dapat menampung aktivitas-aktivitas para anggotanya dalam melaksanakan rencana kerja atau program-program kerja yang telah ditetapkannya.

\section{Masalah pengembangan Organisasi dan SDM}

Dewasa ini pengembangan organisasi di satu sisi merupakan tuntutan yang harus memperoleh perhatian bagi setiap manajemen dan para "pemilik" organisasi. Apakah itu organisasi perusahaan (bisnis), organisasi koperasi, organisasi perguruan tinggi, maupun organisasi sosial masyarakat dan sosial politik. Organisasi dewasa ini dituntut menjadi organisasi yang ramping dan dinamis agar kegiatan yang dijalankan menjadi lebih efektif dan efisien.

Pengembangan organisasi yang dilakukan, akhimya akan berdampak pada masalah sumber daya manusia (SDM). SDM harus tepat dengan pekerjaan yang ada dalam organisasi. SDM harus mendukung kerangka kerja dan mekanisme organisasi, SDM yang mampu mengantisipasi perubahan yang cepat di lingkungannya.

Pengembangan organisasi dan SDM menjadi masalah yang harus segera dijawab setiap manajemen dan enterpreneur untuk menghadapi persaingan dan tantangan lingkungan yang makin mengglobal ini.

\section{Tujuan dan Sasaran Organisasi}

Setiap organisasi memiliki tujuan dan sasaran organisasi. Tujuan biasanya diartikan lebih ideal (kuantifikasinya lebih sulit) dan untuk pencapaian jangka panjang (dari dimensi waktu). Sasaran memiliki kuantifikasi yang lebih mudah (terukur) berdimensi waktu jangka pendek.

Dalam teori manajemen hirarki perencanaan 
memiliki tingkatan sebagai berikut:

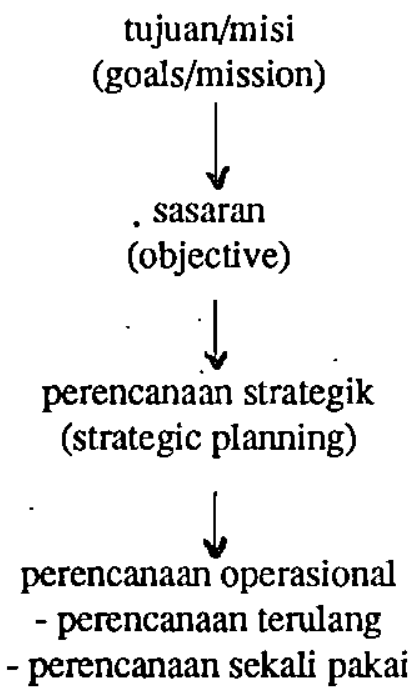

- Tujuan : pemyataan organisasi yang dijadikan arah hasil akhir yang hendak dicapai

- Misi : tujuan organisasi yang dirumuskan untuk mewarnai organisasi dan aktivitas anggotanya

- Sasaran:tujuan organisasi yang lebih terukur (terkuantifikasi), jangka waktu lebih pendek

- Perencanaan strategik : rancangan dengan kegiatan dengan tatacara (sebagai pedoman manajemen saja) untuk mencapai tujuan dan sasaran organisasi

- Perencanaan operasional : rancangan kegiatan yang akan dilaksanakan setiap unit dan personil dalam organisasi untuk mencapai tujuan

- Perencanaan operasional dapat berupa perencanaan terulang dan perencanaan sekali pakai

- Perencanaan terilang : rancangan kegiatan yang selalu diulangi untuk waktu-waktu mendatang. Wujudnya bisa regulasi, kebijakan, prosedur, standard kerja dan sebagainya

- Perencanan sekali pakai : rancangan kegiatan yang hanya dilaksanakan untuk satu satuan waktu berdasarkan sumberdaya yang dimiliki. Wujudnya: proyek, anggaran dan kegiatan yang sifatnya relatif tidak terulang.

Penyusunan organisasi dan pengembangan SDM harus. mampu menterjemahkan tujuan dan misi maupun sasaran organisasi yang diciptakan sekaligus mampu mengoperasionalkan perencanaan strategik yang ditetapkan untuk mencapai sasaran yang ditetapkan.

\section{Pengorganisasian}

Kegiatan untuk membentuk organisasi dinamakan pengorganisasian ("organizing"), seperti G.R. Terry memberikan pengertian organizing adalah alokasi tugas dan pelimpahan atau delegasi kekuasaan. Jadi pengorganisasian merupakan proses pengaturan berbagai macam pekerjaan agar pekerjaan tersebut dapat diselesaikan dengan cara efektif dan efisien.

Telah banyak perusahaan melakukan $r e$ enginering baik secara organisatoris maupun secara proses. Penubahan yang terjadi di lingkungan masyarakat harus diantisipasi secara cermat oleh para manajer, untuk mampu menyesuaikan dan mensiasati agar produk dan atau jasa yang ditawarkan memperoleh respon dari masyarakatnya. Dengan demikian peranan re-enginering dalam organisasi menjadi sebuah kebutuhan.

Dalam usaha penyusunan organisasi agar dapat dipergunakan menjalankan pekerjaan-pekerjaan organisasi yang disepakati bersama secara efektif dan efisien, kiranya beberapa prinsip pengorganisasian yang perlu memperoleh perhatian. Prinsip-prinsip tersebut adalah :

Pertama, organisasi harus mempunyai tujuan yang jelas, artinya merumuskan tujuan yang akan dicapai organisasi baik jangka panjang, jangka menengah dan paling tidak jangka pendek (selama periode kepengurusan).

Kedua, tujuan dan sasaran organisasi harus diterima dan dipahami oleh setiap anggota organisasi. Mereka yang merasa menjadi anggota suatu organisasi, mau dan mampu mengerti, memahami, menerima tujuan/ sasaran bersama tersebut, yang akan dapat dipergunakan alat pengukuran partisipasi anggota dan pengukuran pencapaian hasil pekerjaan/tujuan yang telah disepakatinya.

Ketiga, prinsip pembagian tugas dan wewenang. Artinya bahwa walaupun organisasi ini bersifat sosial dan mengutamakan partisipasi penuh bagi para pengelola (pengurus) maupun bagi anggota organisasi. Namun demikian dalam organisasi semacam ini tetap dituntut adanya pembagian tugas dan wewenang yang jelas/rinci dengan memperhatikan sumber daya manusia yang ada (diskripsi pekerjaan).

Keempat, perlu prinsip hirarki organisasi (mekanisme) yang jelas. Maksudnya adalah bahwa dalam setiap organisasi perlu disusun kedudukan masingmasing unit (satuan) organisasi dalam tata urutan (hirarki) yang jelas, baik yang menyangkut pengambilan keputusan maupun pertanggungjawabannya, sehingga dari padanya menjadi "sehat" dalam arti tidak akan muncul masalah umum dalam organisasi yaitu missunderstanding dan miss-communication.

Kelima, kiranya perlu adanya prinsip pengawasan terutama penetapan "rentang kendali", yaitu berkaitan dengan fungsi pengawasan aktivitas masing-masing unit organisasi maupun pada sétiap anggota organisasi serta perlu adanya sistem pelaporan yang sederhana dan terpadu. 
Keenam, yang juga tidak kalah penting adalah masalah etika dan disiplin organisasi. Pengertian ini lebih pada penekanan mental pegawai, artinya "tatakrama" dan disiplin dalam organisasi harus menjadi gaya atau tipe organisasi dan para anggota personalianya.

\section{Sentralisasi, Desentralisasi dan Integrasi}

Setiap organisasi yang selalu berkembang sering diketemukan adanya perbedaan konsep dari manajemen dan unit-unit pelaksana. Perbedaan tersebut terletak pada mengartikulasikan konsep sentralisasi dan desentralisasi.

Sentralisasi, organisasi yang cenderung segala keputusan berasal dari atas dan atau diatur dari pusat kekuasaan, sedang desentralisasi organisasi yang cenderung segala sesuatunya lebih banyak ditentukan olch unit-unit yang ada di dalam organisasi itu. Dan desentralisasi penyerahan kekuasaan secara penuh pada unit-unit dibawah pusat kekuasaan. Keduanya tentu memiliki keunggulan dan kelemahan sendiri-sendiri.

Dalam tulisan ini diajukan konsep organisasi yang integralistis antara unit-unit dengan kebijakan strategik. Scmentara kebijakan operasional ditetapkan oleh unitunit. Terdapat kebebasan pada unit untuk melakukan berbagai kegiatan yang mengacu kcpada kebijakan pusat dengan manajemen yang terbuka dan terintegrasi diantara unit-unit.

\section{Pengembangan SDM}

Dewasa ini persaingan disegala bidang aktivitas makin ketat. Setiap pemimpin selalu berupaya mencari terobosan untuk mampu bersaing dengan organisasi lain. .Salah satu upaya untuk mampu bersaing adalah melakukan usaha-usaha efektivitas dan efisiensi kerja.

Dalam organisasi yang menawarkan jasa (menjual jasa) pelayanan (services) menjadi sasaran dan dambaan setiap manajemen. Pelayanan kepada pimpinan, pclayanan kepada sesama pegawai dan yang utama dan pertama adalah pelayanan kepada konsumen/masyarakat. Di sinilah letak adanya keunggulan kompetisi antar organisasi.

Dalam organisasi selalu ada sumber daya-sumber daya (manusia, bahan, dana, metode kerja dan fasilitas lainnya).

Setiap organisasi, biaya pegawai merupakan unsur biaya operasional yang paling besar. Oleh karena itu manajemen harus mampu mengembangkan sumber daya manusia (SDM) yang memiliki secara optimal. Mengembangkan di sini diartikan (luas), menambah kemampuan kerja dan pendayagunaan secara optimal.

Pengelolaan SDM menjadi lebih kompleks manakala ditelusuri lagi bahwa akan mengalami kesulitan untuk dapat menurunkan atau menekan biaya ini dalam rangka menghadapi persaingan organisasi.
Yang dapat dilakukan adalah bagaimana dengan biaya SDM yang telah dikeluarkan mampu meningkatkan prestasi kerjanya. Persoalan yang dihadapi menjadi lebih kompleks bagaimana meningkatkan prestasi kerja pegawai perusahaan dengan memberikan motivasi kerja, baik secara material maupun yang bersifat non material. Pembinaan pegawai juga menjadi lebih kompleks, manakala dihubungkan dengan motif dan atau kebutuhan para pegawai dalam bekerja.

\section{Memotivasi Bekerja}

Memotivasi SDM untuk bekerja sesuai dengan tugas dan tanggungjawabnya bukan persoalan yang mudah dilaksanakan. Telah banyak diperbuat para manajer untuk pengembangan SDM, mereka telah membuat berbagai peraturan dan ketentuan dalam kerja (mis. deskripsi jabatan dan ketentuan lainnya), sistem pengupahan yang memadai, maupun telah memberikan program pengembangan SDM dan program-program yang lainnya. Namun demikian belum pula permasalahan di bidang ini dapat terjawab lebih baik, usaha mempertahan prestasi yang telah dicapai saja mengalami kendala, apalagi upaya untuk meningkatkan prestasi kerja.

Oleh karena itu setiap manajer harus mampu mencari berbagai upaya untuk memotivasi para pegawainya, agar tetap memiliki komitmen yang tinggi terhadap organisasi. Hal ini dapat dilakukan dengan melihat lebih jauh tentang motivasi seseorang melakukan pekerjaan, mengingat motivasi bekerja seseorang sangat majemuk, kompleks, dan dapat berubah-ubah. Seperti Lawrence Wangler menyatakan bahwa pada sebagian orang merasa nilai-nilai dasar pekerjaan telah berubah. -Beberapa tahun yang lalu terdapat asumsi bahwa suatu "etnik kerja" memotivasi karyawan untuk bekerja lebih keras sesuai dengan kemampuan terbaik yang dapat mereka lakukan. Dewasa ini sebagian orang merasa bahwa komitmen seperti itu terhadap pekerjaan telah mengendur. Jika demikian halnya, maka upaya memotivasi pegawai akan menjadi lebih sukar. (lihat Gary Dessler, terj., 1986, hal.5). Sementara itu berdasar bcberapa ahli disebutkan bahwa sebab-sebab seseorang bckerja adalah :

1. Kesempatan untuk mengerjakan sesuatu yang dapat membuat dirinya senang/bahagia.

2. Kesempatan untuk menyelesaikan sesuatu yang amat berharga bagi dirinya.

3. Kesempatan untuk mempelajari sesuatu.

4. Kesempatan untuk mengembangkan ketrampilan dan kemampuannyd.

5. Karena adanya kebebasan dalam pelaksanaan kerja. (Heidjerachman R., 1990, hal. 118) 
Manajer, harus memahami bahwa pada dewasa ini motivasi seseorang bekerja telah dan sedang berubah, dan hal ini disadari bahwa motif seseorang dalam bekerja sangat majemuk, mudah berubah, berbeda dari orang yang satu dengan yang lainnya. Disamping itu menurut Keypers membagi motif seseorang dibedakan menjadi motif biologik, motif sosiologik dan motif teologik. Motif biologik yang berhubungan dengan kebutuhan pokok untuk kelangsungan hidup, motif sosiologik berkaitan dengan interaksi antar individu dan motif teologik berhubungan mental spiritual yaitu hubungan manusia dengan Al-Kholiq (Allah SWT).

Abraham A Maslow memberikan hirarki kebutuhan manusia sebagai sarana penggerak (motivasi) dalam bekerja menjadi lima kebutuhan yang disusun secara bertingkat. Dimulai dari tingkatan yang paling dasar. dengan urutan secara hirarki seperti gambar berikut:

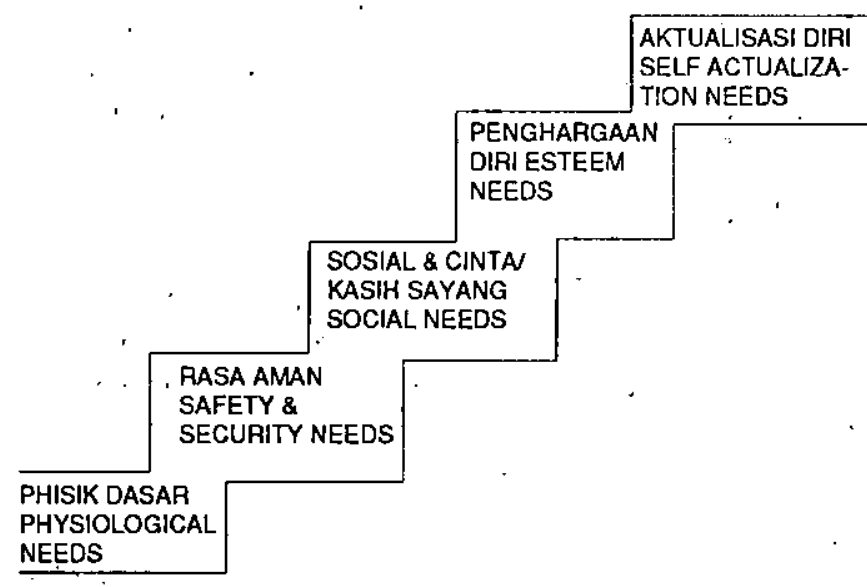

\section{Pemenuhan Motif}

Kiranya telah banyak dilakukan pada setiap organisasi untuk memberikan dan memenuhi kebutuhan atau motif yang bersifat primer (biologis), maupun kebutuhan sekunder yang bersifat material. Karena telah memberikan gaji/upah dan pembayaran yang lain bagi SDM nya secara memadai, paling tidak memenuhi kebutuhan perundangan ketentuan yang berlaku.

Disamping itu telah banyak melaksanakan program-program pembinaan SDM dalam bentuk pengembangan di bidang pengetahuan dan ketrampilan bekerja. Program ini dilaksanakan untuk meningkatkan kemampuan SDM dalam menjalankan kegiatan sesuai dengan jabatan yang telah ditetapkan. Wawasan dan pengetahuan lebih banyak menekankan pada aspek bekerja yang cenderung ke arah kognitif dan psikomotorik.

Manakala program dan kegiatan yang telah dilaksanakan tersebut belum memenuhi harapan SDM agar mampu memberikan kontribusi prestasi yang memadai, maka manajemen harus selalu berupaya mencari dan meneliti sampai dimana motivasi bekerja SDM nya. Apakah mereka perlu pembinaan mental spiritual, apakah mereka perlu fasilitas, perlu rekreasi, perlu pengupahan yang besar dan sebagainya. Kita lihat hirarki Maslow tersebut.

Misal mengenai pembinaan mental pegawai ini dapat dilakukan dengan 2 jenis pembinaan yaitu pembinaan mental spiritual dan pembinaan mental sistem interaksi (pembinaan mental interaksional). Pembinaan mental spiritual dimaksudkan sebagai upaya pembinaan jiwa seseorang untuk memelihara dan meningkatkan ketaqwaan kepada Allah SWT. Manusia merupakan makhluk Allah SWT. yang bertaqwa kepadaNya, dengan memiliki kewajiban sebagai hamba Allah untuk melakukan ibadah-ibadahnya. Pembinaan pada jenis ini menuntut para manajer harus mampu memberikan sarana dan prasarana untuk melakukan ibadah tersebut bagi pegawainya (biaya naik haji misalnya).

Pembinaan mental interaksional dimaksudkan adalah pembinaan yang dilakukan untuk meningkatkan perilaku dan budi pekerja baik dalam hubungan antar pegawai dan upaya melaksanakan regulasi-regulasi dan . tradisi-tradisi organisasi yang telah biasa terjadi (mestinya lebih menekankan tradisi dibanding regulasi). Perilaku organisasi yang telah ada dan telah lama disepakati hendaknya dilaksanakan dan dikembangkan secara positif dari perlu dikembangkan sikap saling hormat menghormati, berperilaku positif terhadap sesama pegawai. Disadarkan bahwa setiap organ dan . pegawai memiliki andil bersama bagi kemajuan perusahaan, sesuai dengan kedudukan. dan tugasnya. Kebiásaan yang telah berjalan hendaknya dikembangkan secara positif misalnya, telah menjadi kebiasaan bahwa pada setiap akhir tahun dilakukan pertemuan secara keseluruhan untuk masing-masing unit untuk melakukan evaluasi dan perencanaan lanjutan, hendaknya tetap dijalankan. Bagi mereka yang berprestasi mendapat insentif tertentu hendaknya dikembangkan lebih positif lagi. Manajer harus juga transparan terhadap para pegawai, manakala perusahaan mempunyai keuntungan atau mencapai sukses harus juga dinyatakan bahwa organisasi sukses (untung), manakalah para pegawai telah berprestasi dalam mendukung pencapaian keuntungan perusahaan harus pula diakui, bukan sebaliknya, selalu dikatakan pegawai tidak berprestasi.

Strategi yang dikembangkan dalam pembinaan mental pegawai ini adalah kepemimpinan yang berketauladanan, keterbukaan, dan meletakkan manusia sebagai sumberdaya organisasi sebagai kunci sukses dan SDM merupakan asset yang "mahal". 


\section{Daftar Pustaka}

A.W. Wijaya, Administrasi Kepegawaian: Suatu Pengantar, CV. Rajawali, Jakarta, 1986.

Departemen Pendidikan dan Kebudayaan RI, Materi Dasar Pendidikan Program Akta Mengajar V : Buku IID-Pengetahuan Kedinasan, Departemen Pendidikan dan Kebudayaan Direktoral Jenderal Pendidikan Tinggi, Jakarta, 1983/1984.

Gary Dessler, (Terj.), Manajemen Personalia, Edisi Ketiga, Penerbit Erlangga, Jakarta, 1984.

Heidjrachman Ranupandojo dan Sụad Husnan, Manajemen Personalia, LMP2M-AMP YKPN, Yogyakarta, 1987.

,Dasar-Dasar Manajemen, Unit Penerbit dan Percetakan AMP YKPN, Yogyakarta, 1990.

James L. Gibson, John M. Ivancevich dan James H. Donnelly Jr., (Terj.), Organisasi-Perilaku; Struktur; Proses, Jilid 1, Penerbit Erlangga, Jakarta, 1987.

Moh. As'ad, Kepemimpinan Efektif dalam Perusahaan: Suatu Pendekatan Psikologik. Edisi II, Penerbil
Liberty, Yogyakarta, 1986.

, Kepemimpinan Efektif dalam Perusahaan, Edisi Kedua, Liberty, Yogyakarta, 1986.

Mochtar Effendy, Manajemen Suatu Pendekatan Berdasarkan Ajaran Islam, Penerbit Bhratara Karya iksara, Jakarta, 1986. Musyawarah Nasional, Hasil Keputusan Musyawarah Alumni UII 1986, Pengurus Pusat Alumni UII, Yogyakarta, 1.987.

Slamet Saksono, Administrasi Kepegawaian, Penerbit Kanisius, Yogyakarta, 1988.

Sondan P Siagian, Manajemen Sumber Daya Manusia, Bumi Aksara, Jakarta, 1992.

Sudibyo Triatmodjo, Hukum Kepegawaian, Ghalia Indonesia, Jakarta, 1983.

Sentanoe Kertonegoro, Prinsip dan Teknik Manajemen, Ananda \& Lembaga Kerja Sama Pendidikan Tinggi Akuntansi Swasta Indonesia, Yogyakarta, 1985.

T. Hani Handoko, Manajemen, Edisi II, BPFE dan LMP2M AMP-YKPN, Yogyakarta, 1986. 